1 Keating FR, Parkin TW, Selby JB, Dickinson LS. Treatment of heart disease associated with myxoedema. Prog Cardiovasc Dis 1961;3:364-81

2 Levine HD. Compromise therapy in the patient with angina pectoris and hypothyroidism. Am 7 Med 1980;69:411-8.

3 Hay ID, Duick DS, Vlietstra RE, Maloney JD, Pluth JR. Thyroxine therapy in hypothyroid patients undergoing coronary revascularisation: a retrospective analysis. Ann Intern Med 1981;95:456-7.

4 Evered D, Young ET, Ormston BJ, Menzies R, Smith PA, Hall R. Treatment of hypothyroidism: a reappraisal of thyroxine therapy. BrMed F 1973;iii:131-4

5 Larsen PR, Silva JE, Kaplan MM. Relationship between circulating and intracellular thyroid hormones: physiological and clinical implications. Endocr Rev 1981;2:87-102.

6 Nicoloff JT, Lum SMC, Spencer CA, Morris R. Peripheral autoregulation of thyroxine to triiodothyronine conversion in man. Horm Metab Res (Suppl) 1984;14:74-9.

7 Dyer C. Dr Gee defends his treatment. Br Med f 1984;289:1683-4.

8 Jackson IMD, Cobb WE. Why does anyone still use desiccated thyroid USP? Am $\mathcal{J}$ Med \begin{tabular}{l}
$1978 ; 64: 284-8$. \\
\hline
\end{tabular}

9 Evered DC, Ormston BJ, Smith PA, Hall R, Bird T. Grades of hypothyroidism. Br Med $\mathcal{F}$ 1973;i:657-62.

10 Bell GM, Sawers JSA, Forfar JC, Doig A, Toft AD. The effect of minor increments in plasma thyroxine on heart rate and urinary sodium excretion. Clin Endocrinol (Oxf) 1983;18:511-6.

11 Jennings PE, O'Malley BP, Griffin KE, Northover B, Rosenthal FD. Relevance of increased serum thyroxine concentrations associated with normal serum triiodothyronine values in hypothyroid patients receiving thyroxine: a case for "tissue thyrotoxicosis." $\mathrm{Br}$ Med $\mathcal{J}$ 1984;289:1645-7.

12 Beckett GJ, Kellett HA, Gow SM, Hussay AJ, Hayes JD, Toft AD. Elevated plasma glutathione $\mathrm{S}$-transferase concentrations in hyperthyroidism and in hypothyroid patients receiving $\mathrm{S}$-transferase concentrations in hyperthyroidism and in hypothyroid
thyroxine replacement: evidence for hepatic damage. $\mathrm{Br}$ Med $\mathrm{f}$ (in press).

13 Weller CV, Wanstrom RC, Gordon H, Bugher JC. Cardiac histopathology in thyroid disease. Am Heart $\mathcal{X}$ 1932;9:8-12.

14 Parker JLW, Lawson DH. Death from thyrotoxicosis. Lancet 1973;ii:894-5.

15 Pearce CJ, Himsworth RL. Total and free thyroid hormone concentrations in patients receiving maintenance replacement treatment with thyroxine. Br Med f 1984;288:693-5.

\section{Blood transfusion and surgery}

Concern about the acquired immune deficiency syndrome (AIDS) has resulted in major changes in blood transfusion practice in the United States and its impact is now making itself felt in Britain. Although the risk of acquiring AIDS by blood transfusion seems to be remote, and certainly less than that of developing hepatitis, it has provoked a timely reappraisal of attitudes to transfusion. Recent advances in laboratory techniques have reduced the time taken to perform a safe cross match to 30 to 40 minutes. Thus provided the patient has been grouped and screened for antibodies any surgical procedure that seldom causes loss of more than $20 \%$ of the total blood volume should no longer routinely be covered by two or three units of cross matched blood.

Ten years ago Sykes recommended that losses of this order should be replaced with non-sanguineous fluids. ' But this has not happened, chiefly because cross matched blood has usually been readily available. Nevertheless, cross matching of blood does nothing to reduce the incidence of the four or more serious diseases transmitted by viruses, nor of anaphylactic and delayed haemolytic reactions. ${ }^{2}$ The development of crystalline haemoglobin solutions and perfluorocarbons has not yet got to the stage where either of them has advantages over plasma or plasma substitutes.

Studies from different countries of the ratio of blood cross matched to blood transfused during routine operations show that practice is remarkably similar for procedures for which two or three units of blood are cross matched but seldom used. . $^{3.6}$ Seshadri and his colleagues have instituted a maximum order for blood for all routine elective operations, and this is adhered to unless the patient has antibodies or there are other unusual circumstances. ${ }^{5}$ Arguably it is time for British hospitals, which at present have a service based on arbitrary request, to adopt a similar approach.

There has never been any justification for transfusing a patient before elective surgery simply on the grounds that it might be expedient, and now patient resistance will probably, and rightly, put a stop to it. The accepted lower limit of haemoglobin of $10 \mathrm{~g} / \mathrm{dl}$ should not be abandoned: it represents a loss of about $25 \%$ of the oxygen carrying capacity of the blood and no anaesthetist can guarantee not to let his or her patient's cardiac output fall during the operation. Concentrations below $10 \mathrm{~g} / \mathrm{dl}$ are accompanied by a progressive increase in the bleeding time, ${ }^{7}$ and below $9 \mathrm{~g} / \mathrm{dl}$ the compensatory increase in dissociation of oxyhaemoglobin will no longer prevent a decrease in cardiac output. ${ }^{8}$

Demand for designated blood, either from relatives or by one of the methods making use of autologous blood, ${ }^{9}$ is increasing. Its application is necessarily restricted but it may prove useful in paediatric surgery and for operations that have a relatively predictable blood loss. Blood taken from relatives and by the so called predeposit autologous method (by which blood is taken from the patient days or even weeks preoperatively) is not popular with transfusion staff, who are understandably reluctant to see a two tier system develop. ${ }^{10}$ Yet, if clinicians become responsible for taking, storing, and administering such blood the present high standards of the transfusion service seem unlikely to be maintained. This problem may be overcome if autologous blood-obtained either by salvage autotransfusion or by deliberate haemodilution-is used. In salvage autotransfusion blood lost during surgery is collected and reinfused and this method deserves wider application than it has so far achieved. Deliberate haemodilution entails bleeding patients at the induction of anaesthesia and maintaining normovolaemia by infusion of clear fluids. This method is particularly suitable for patients whose haemoglobin concentrations are above the normal range, for high concentrations, in contrast to low ones, are known to be associated with increased surgical morbidity and mortality. ${ }^{1.15}$ The patient is bled until the packed cell volume reaches a predetermined level, usually $35 \%$, and the blood is anticoagulated and then reinfused to cover subsequent operative loss. ${ }^{16}$

In the United States active transfusion committees are a requirement of the Joint Commission on Accreditation of Hospitals. ${ }^{17}$ In the current ferment of public and professional concern about blood transfusion, hospitals in Britain would do well to follow this practice. If they drag their feet this may prove to be an aspect of clinical practice that will be called to account by their new managers.

P J HORSEY

Consultant Anaesthetist,

Southampton General Hospital,

Southampton SO9 4XY

1 Sykes MK. Indications for blood transfusion. Can Anaesth Soc $\mathcal{f}$ 1975;22:3-11.

2 Pineda AA, Taswell HF, Brzica SM. Delayed hemolytic transfusion reaction; an immunologic hazard of blood transfusion. Transfusion 1978;18:1-7.

3 Devitt JE. Blood wastage and cholecystectomy: a spin off from a peer review. Can Med Assoc 1973;109:120-1.

4 Rouault C, Greunhagen J. Reorganisation of blood ordering practices. Transfusion 1978;18: $448-53$.

5 Seshadri RS, Odell WR, Roxby D, Morley AA. Effective use of blood in elective surgical procedures. Med f Aust 1979;ii:575-8.

6 Dodds AJ, Pun A, Isbister JP, et al. A rational approach to crossmatching blood for elective surgery. Anaesth Intensive Care 1983;11:16-9.

7 Anonymous. The bleeding time and the haematocrit [Editorial]. Lancet 1984;i:997-8.

8 Gillies IDS. Anaemia and anaesthesia. Br f Anaesth 1974;46:589-602.

9 Horsey PJ. Blood transfusion. In: Atkinson RS, Hewer CLA, eds. Recent advances in anaesthesia and analgesia 14. London: Churchill Livingstone, 1982:89-103.

10 Bove JR. Transfusion associated AIDS-a cause for concern. N Engl f Med 1984;310:115-6.

11 Elwood PC. Anaemia. Lancet 1974;ii:1364-5.

12 Bouhoutsos J, Morris T, Chevatzas D, Martin P. The influence of haemoglobin and platelet levels on the results of arterial surgery. BrF Surg 1974;61:984-6.

13 Baily MJ, Johnston CLW, Yates CJP, Somerville PG, Dormandy JA. Preoperative haemoglobi as a predictor of outcome in diabetic amputations. Lancet 1979;ii:168-70.

14 Yates CJP, Berent A, Andrews V, Dormandy JA. Increase in leg blood flow by normovolaem haemodilution in intermittent claudication. Lancet 1979;ii: 166-8.

15 Anonymous. Haemoglobin and the ischaemic foot [Editorial]. Lancet 1979;ii:184-5.

16 Meemer K, Schmidt-Schonbein H, eds. International hemodilution. Basle: S Karger, 1975.

17 Grindon AJ, Tomasulo PS, Bergin JJ, Klein HG, Miller JD, Mintz PD. The hospital transfusion committe; guidelines for improving practice. FAMA 1985;253:540-3. 